\title{
Research on Dynamic Responses of Long-Span Suspension Bridge with CFRP Cables
}

\author{
Lei Yang ${ }^{1, a}$, Fei Shao ${ }^{2, b}$, Kebin Jiang ${ }^{3, c}$,Xingming Zhang ${ }^{4, d}$ \\ ${ }^{1,2,3}$ College of Field Engineering.PLA Univ. of Sci \& Tech. 210007 Nanjing, china \\ ${ }^{4}$ School of highway, Chang'an University. 710064 Xi'an,china \\ a137854629@qq.com, ${ }^{\text {b }}$ shaofeiriver@163.com, ${ }^{\text {ckbjiang@sina.com, }{ }^{d} 969439688 @ q q . c o m}$
}

Keywords:Suspension bridge, CFRP, Dynamic properties, ANSYS

Abstract: In order to study the dynamic responses of long-span suspension bridge with CFRP cables, a suspension bridge with CFRP cables which span of $896 \mathrm{~m}$ is designed. The dynamic responses of suspension bridge with steel cables and CFRP cables are analyzed by ANSYS software, the effects of structural design parameters on the dynamic responses are investigated. The analysis results show the basic frequency of vertical, lateral bending and twist of suspension bridge with CFRP cables were increased in contrast with suspension bridge with steel cables, applying CFRP cable has little effect on the mode shapes and frequencies of horizontal bending and longitudinal floating of stiffening girder, the central buckle could improve the dynamic behavior of suspension bridge, the frequency not always increase with the stiffness of main cables increase, the stiffness of suspender have relatively little effect on the dynamic behavior of the entire suspension bridge.

\section{Introduction}

Suspension bridge is a flexible suspension system, which composed by main cables and stiffening girder. It has been widely used in the long-span bridge duo to its strong leap ability. suspension bridge is easily vibrated by environment loads which include wind loads, vehicle loads, seismic loads and so. The traditional suspension bridge use steel cables, it can meet the need of engineering of medium span bridge, the gravity of steel cables become a major factor with the increase of span, it restrict the leap ability of suspension bridge and decrease the efficiency of bearing capacity. Carbon-fibre reinforced plastic[2-5] possess the characteristics of high strength, light weight, good abradability, non-corrosion, good durability, and high fatigue resistance, which is suitable as cables for long-span suspension bridge to solve the above problems. The dynamic behavior[6] is essential to the research on structural dynamic characteristic. It is essential to study the long-span suspension bridge with CFRP cables.

\section{Characteristics of CFRP}

CFRP[7] is an composite material of light weight and high strength, compounded by resin and carbon fiber, and take full advantage of carbon fiber and resin. The CFRP material of different manufacturers have some differences in CFRP characteristics, CFRP characteristics is shown in Table 1. According to figure 1, CFRP cables is linear variation before breakage. 
Table 1 Properties of CFRP-wires and tensioning steel

\begin{tabular}{|c|c|c|c|c|}
\hline Type of cable & A & B & $\mathrm{C}$ & steel \\
\hline Bulk density $\left(\mathrm{kN} / \mathrm{mm}^{2}\right)$ & 16 & 16 & 16 & 77 \\
\hline Strength of extension( $(\mathrm{MPa})$ & $2: 140$ & 2550 & 2022 & 1570 \\
\hline Elasticity modulus $\left(\mathrm{kN} / \mathrm{mm}^{2}{ }^{2}\right)$ & 137 & 147 & 137 & 196 \\
\hline $\begin{array}{l}\text { Strength of } \\
\text { extension/elasticity modulus }\end{array}$ & 0.016 & 0.017 & 0.015 & 0,008 \\
\hline Relax rate in 1000 hours(\%) & 0.3 & 0.3 & 0.3 & $<2.5$ \\
\hline Failure strain( $(\%)$ & 1.6 & 1.6 & 2.0 & $3-4$ \\
\hline $\begin{array}{l}\text { Coefficient of linear } \\
\text { Expansion }\left(\times 10^{-6}\right)\end{array}$ & 0.6 & 0.68 & 0.6 & 12 \\
\hline
\end{tabular}

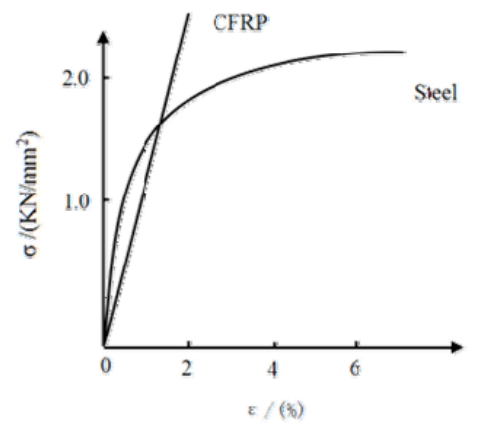

Figure 1 Stress-strain curves of CFRP cable and steel cable

\section{Finite element analysis of suspension bridge with CFRP cables in dynamic behavior}

The dynamic responses of suspension bridge is directly related with the safety of bridge. The main structural part are composed of main cables, bridge tower, the stiffening girder, suspender and anchorage. The long-span suspension bridge engineering background of this paper include, main span of the bridge is $896 \mathrm{~m}$, the stiffening girder use truss structural, the wide of girder is $28.2 \mathrm{~m}$, the truss structural is composed of main truss, top and bottom bracing, the transverse truss, use CFRP cables, the transverse space of CFRP cables is $26 \mathrm{~m}$, the rise-span ratio is $1 / 10.5$, the bridge tower use portal frame in concrete structure, the height of tower is $122.1 \mathrm{~m}$. ANSYS software was been used to Build the finite model of the bridge. The linetype of cable use the formula[8]: $y=\frac{4 f(l-x) x}{l^{2}}$, where $y$ represents Y-axis, $x$ represents $\mathrm{X}$-axis, $l$ represents the main span, $f$ represents the rise-span ratio. The finite model of suspension bridge shown in figure 2 .

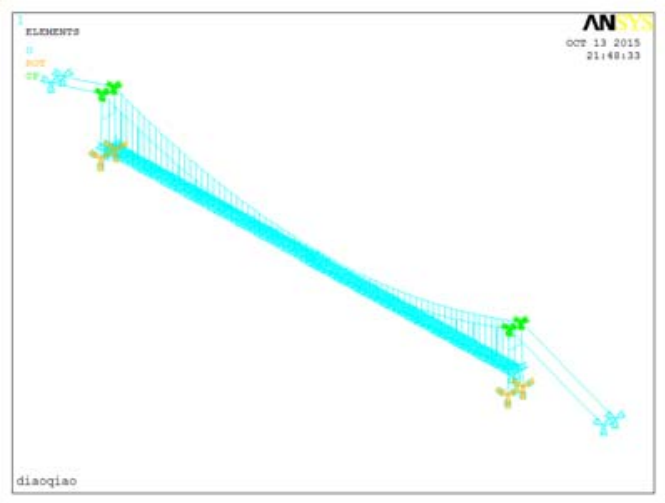

Figure 2 Finite model of suspension bridge

Modal analysis is necessary to study the dynamic characteristics of the structural. Through the Modal analysis of suspension bridge with CFRP cables, the first ten natural frequencies and mode shapes are gained. The main steps of modal analysis include: firstly, have static analysis on the finite model. The effect of large deformation and prestressing should consider in static analysis. Secondly, have modal analysis on the finite model. Thirdly, mode expansion. The last, post processing and view results. The first six mode of vibration about suspension bridge is shown in figure 3, the preceding 10 primary modal analysis results are listed in table 3 . The modal characteristic are described with abbreviations: H-horizontal, V-vertical, L-Longitudinal, B-bending, T-torsion, F-floating, S-symmetric, A-anti-symmetric, SG-stiffening girder, MC-main cables.

According to the results in figure 3 and table 3, the main mode shapes of the first ten mode shapes of suspension bridge with CFRP cables are the vibration of girder and cable. The fist six mode shapes are the vibration of girder, the first order vibration is the lateral bending of symmetrical, the fundamental frequency is $0.069555 \mathrm{~Hz}$. 

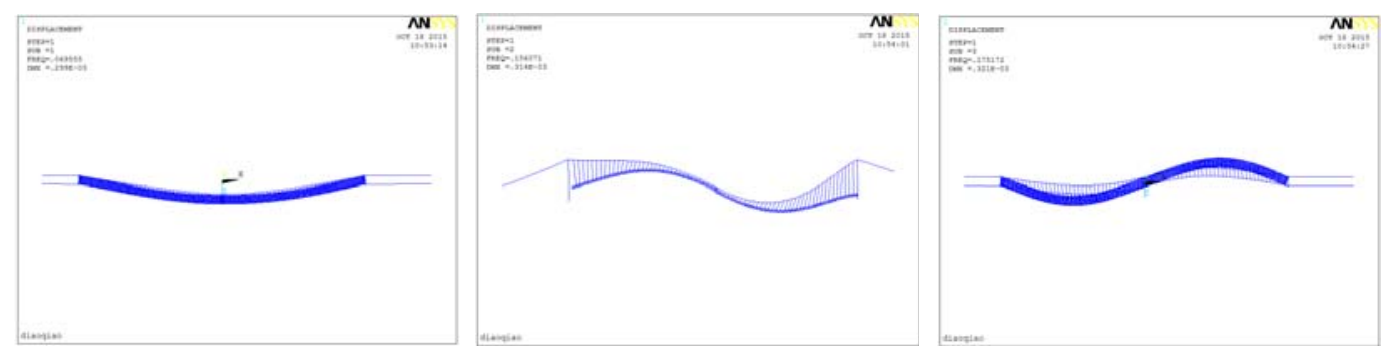

(a) 1st S-HB

(b) 1 st A-VB

(c) 2st A-HB
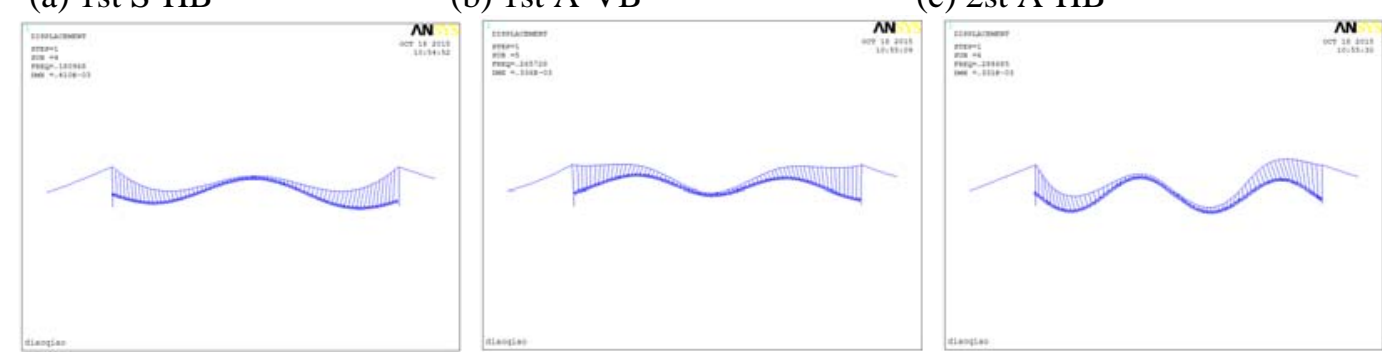

(d) 2st S-VB

(e) 3st S-VB

(f) 2 st A-VB

Figure 3 Mode of vibration about suspension bridge

Table 3 Fundamental frequency and mode of suspension bridge with CFRP cables

\begin{tabular}{cccc}
\hline Mode No. & $\begin{array}{c}\text { Frequency } \\
(\mathrm{Hz})\end{array}$ & $\begin{array}{c}\text { Mode shape } \\
\text { description }\end{array}$ & Period (s) \\
\hline 1 & 0.069555 & 1st S-HB & 14.38 \\
2 & 0.15607 & 1st A-VB & 6.41 \\
3 & 0.17517 & 2st A-HB & 5.71 \\
4 & 0.18097 & 2st S-VB & 5.53 \\
5 & 0.26573 & 3st S-VB & 3.76 \\
6 & 0.28869 & 2st A-VB & 3.46 \\
7 & 0.31492 & 2st S-HB & 3.18 \\
8 & 0.383 & 4st S-VB & 2.61 \\
9 & 0.38997 & 1st S-T & 2.56 \\
10 & 0.46619 & 2st S-T & 2.15 \\
\hline
\end{tabular}

\section{Dynamic responses comparison between suspension bridge with CFRP cables and steel cables}

The paper remain the parameters of the bridge unchanged, use the equivalent stiffness method[7] to calculate the cross-sectional area of the steel cable, analyze the dynamic responses of suspension bridge with steel cables.The equivalent stiffness method: $E_{1} A_{1}=E_{2} A_{2}$, where, $E_{1}, E_{2}$ represent elasticity modulus of CFRP and steel separately, $A_{1}, A_{2}$ represent cross-sectional area of CFRP cable and steel cable separately.The fundamental frequency and mode of suspension bridge with steel cables are listed in table 4 . The fundamental frequency and mode of several suspension bridges are listed in table 5. 
Table 4 Fundamental frequency and mode of suspension bridge with CFRP cables

\begin{tabular}{cccc}
\hline Mode No. & $\begin{array}{c}\text { Frequency } \\
(\mathrm{Hz})\end{array}$ & Mode shape description & $\begin{array}{c}\text { Period } \\
(\mathrm{s})\end{array}$ \\
\hline 1 & 0.068218 & 1st S-HB & 14.66 \\
2 & 0.15056 & 1st A-VB & 6.64 \\
3 & 0.17295 & 2st A-HB & 5.78 \\
4 & 0.17583 & 2st S-VB & 5.69 \\
5 & 0.25097 & 3st S-VB & 3.98 \\
6 & 0.2802 & 2st A-VB & 3.57 \\
7 & 0.30297 & 2st S-HB & 3.30 \\
8 & 0.33072 & 1st S-T & 3.02 \\
9 & 0.33589 & 1st S-T & 2.98 \\
10 & 0.3544 & 2st S-T & 2.82 \\
\hline
\end{tabular}

Table 5 Fundamental frequency and mode of several suspension bridges [5-6]

\begin{tabular}{cccccc}
\hline Bridge name & $\begin{array}{c}\text { Main } \\
\text { span(m) }\end{array}$ & $\begin{array}{c}\text { Type of } \\
\text { stiffening } \\
\text { girder }\end{array}$ & Frequency(Hz) Period(s) & $\begin{array}{c}\text { Mode shape } \\
\text { description }\end{array}$ \\
$\begin{array}{c}\text { Runyang yangtze } \\
\text { river bridge }\end{array}$ & 1490 & Steel box girder & 0.0498 & 20.08 & 1 st S-HB \\
$\begin{array}{c}\text { Jiangyin yangtze } \\
\text { river bridge }\end{array}$ & 1385 & Steel box girder & 0.0521 & 19.19 & 1 st S-HB \\
$\begin{array}{c}\text { Hong Kong } \\
\text { Tsingma bridge }\end{array}$ & 1377 & $\begin{array}{c}\text { Steel truss } \\
\text { girder }\end{array}$ & 0.068 & 14.71 & 1 1st S-HB \\
$\begin{array}{c}\text { Yichang Yangtze } \\
\text { river bridge }\end{array}$ & 960 & Steel box girder & 0.0705 & 14.18 & 1 1st S-HB \\
$\begin{array}{c}\text { Humen bridge } \\
\text { Haicang bridge }\end{array}$ & 888 & Steel box girder & 0.0921 & 10.86 & 1 1st S-HB \\
\hline
\end{tabular}

According to the results in table 3 and table 4, in contrast with suspension bridge with steel cables, the fundamental frequency of suspension bridge with CFRP cables increased, and the low order improve more than high order, the result can illustrate that suspension bridge with CFRP cables possess good dynamic responses. According to the results in table 5, the fundamental frequency increase with the main span increase, the fundamental frequency of suspension bridge with steel cables get close to the Yichang Yangtze river highway bridge, the result illustrate the accuracy of the finite model in this paper.

\section{Analyze the effects of structural design parameters of suspension bridge with CFRP cables on the dynamic responses}

The paper use simple variable method to analyze the dynamic responses of suspension bridge with CFRP cables models which possess different structural parameters.

\section{Effects of central buckle}

Central buckle is a effective measure to improve the entire stiffness of suspension bridge. Modal analysis of the effects of central buckle is shown in table 6 which list the fist ten mode shapes only. 
Table 6 Dynamic responses of suspension bridge with central buckle or suspender

\begin{tabular}{ccccc}
\hline \multirow{2}{*}{$\begin{array}{c}\text { Mode } \\
\text { No. }\end{array}$} & \multicolumn{2}{c}{ Central buckle } & \multicolumn{2}{c}{ Suspender } \\
\cline { 2 - 5 } & $\begin{array}{c}\text { Frequenc } \\
\mathrm{y}(\mathrm{Hz})\end{array}$ & $\begin{array}{c}\text { Mode shape } \\
\text { description }\end{array}$ & $\begin{array}{c}\text { Frequenc } \\
\mathrm{y}(\mathrm{Hz})\end{array}$ & $\begin{array}{c}\text { Mode shape } \\
\text { description }\end{array}$ \\
\hline 1 & 0.069555 & 1st S-HB & 0.069106 & 1st S-HB \\
2 & 0.15607 & 1st A-VB & 0.13605 & 1st A-VB \\
3 & 0.17517 & 2st A-HB & 0.16507 & 1st A-HB \\
4 & 0.18097 & 2st S-HB & 0.1809 & 2st S-VB \\
5 & 0.26573 & 3st S-VB & 0.26445 & 3st S-VB \\
6 & 0.28869 & 2st S-VB & 0.28137 & 2st A-VB \\
7 & 0.31492 & 2st S-HB & 0.31347 & 2st S-HB \\
8 & 0.383 & 4st S-VB & 0.37079 & 4st S-VB \\
9 & 0.38997 & 1st S-T & 0.41336 & 1st S-T \\
10 & 0.46619 & 2st S-T & 0.41593 & 2st S-T \\
\hline
\end{tabular}

The fundamental frequency of model that have suspender is $0.0691 \mathrm{~Hz}$, but the fundamental frequency of model that have central buckle is $0.0695 \mathrm{~Hz}$, it improve a lot by comparison, the reason is that central buckle restrict the longitudinal displacement of suspension bridge, and make the entire stiffness of the bridge improve.

\section{Effects of the stiffness of main cable}

The stiffness of main cable is the product of cross-sectional area and elasticity modulus, the elasticity modulus of the material is unchanged, so the stiffness of the cable depend on the cross-sectional area. The paper use relative stiffness coefficient $\eta_{1}$ to represent the change of stiffness, $\eta_{1}=\frac{E A}{E_{0} A_{0}}$, where $E_{0} A_{0}$ represents the standard stiffness, $E A$ represents the changed stiffness. Modal analysis of the effects of the stiffness of the cable are shown in table 7 which list the fist ten mode shapes only.

According to the results in table 7, most of the fundamental frequency of the bridge increase with $\eta_{1}$ increase, but the lateral bending of symmetrical of second order and the torsion of second order are increase at first and then decrease. The change of the stiffness of cable leads to the gravity of the bridge increase and make the original balance of the bridge break. In conclusion, the fundamental frequency of suspension bridge not always increase with the stiffness of the main cable increase.

Table 7 Dynamic responses of suspension bridge with different $\eta_{1}$

\begin{tabular}{|c|c|c|c|c|c|c|c|c|c|c|}
\hline \multirow{3}{*}{$\begin{array}{c}\text { Mode } \\
\text { No. }\end{array}$} & \multicolumn{10}{|c|}{$\eta_{1}$} \\
\hline & \multicolumn{2}{|c|}{0.5} & \multicolumn{2}{|c|}{0.8} & \multicolumn{2}{|r|}{1} & \multicolumn{2}{|c|}{1.5} & \multicolumn{2}{|r|}{2} \\
\hline & $\begin{array}{c}\text { Frequency } \\
(\mathrm{Hz})\end{array}$ & $\begin{array}{l}\text { Mode shape } \\
\text { description }\end{array}$ & $\begin{array}{c}\text { Frequency } \\
(\mathrm{Hz})\end{array}$ & $\begin{array}{l}\text { Mode shape } \\
\text { description }\end{array}$ & $\begin{array}{l}\text { Frequency } \\
(\mathrm{Hz})\end{array}$ & $\begin{array}{l}\text { Mode shape } \\
\text { description }\end{array}$ & $\begin{array}{l}\text { Frequency } \\
(\mathrm{Hz})\end{array}$ & $\begin{array}{l}\text { Mode shape } \\
\text { description }\end{array}$ & $\begin{array}{c}\text { Frequency } \\
(\mathrm{Hz})\end{array}$ & $\begin{array}{l}\text { Mode shape } \\
\text { description }\end{array}$ \\
\hline 1 & 0.068221 & 1st S-HB & 0.069208 & 1st S-HB & 0.069555 & 1st S-HB & 0.069989 & 1st S-HB & 0.070146 & 1st S-HB \\
\hline 2 & 0.14947 & 1st A-VB & 0.15449 & 1st A-VB & 0.15607 & 1st A-VB & 0.15789 & 1st A-VB & 0.15842 & 1st A-VB \\
\hline 3 & 0.1619 & 2st A-VB & 0.17397 & 2st A-VB & 0.17517 & 2st A-HB & 0.17705 & 2st A-HB & 0.1781 & 2st A-HB \\
\hline 4 & 0.17119 & 2st A-HB & 0.17639 & 2st S-VB & 0.18097 & 2st S-VB & 0.18636 & 2st S-VB & 0.18859 & 2st S-VB \\
\hline 5 & 0.21884 & 1st S-VB & 0.24754 & 3st A-VB & 0.26573 & 3st S-VB & 0.28996 & 4st A-VB & 0.29044 & 4st A-VB \\
\hline 6 & 0.28233 & 4st A-VB & 0.28708 & 4st A-VB & 0.28869 & 2st A-VB & 0.30435 & 3st A-VB & 0.31332 & 3st A-VB \\
\hline 7 & 0.31364 & 2st S-HB & 0.3149 & 2st S-HB & 0.31492 & 2st S-HB & 0.31433 & 2st S-VB & 0.33091 & 2st S-VB \\
\hline 8 & 0.32485 & 1st A-T & 0.36796 & 1st S-T & 0.383 & 4st A-VB & 0.38991 & 1st S-T & 0.39937 & 1st S-T \\
\hline 9 & 0.37314 & 5st S-VB & 0.37995 & 5st S-VB & 0.38997 & 1st S-T & 0.42713 & 5st A-VB & 0.44026 & 5st S-VB \\
\hline 10 & 0.46473 & 2st S-T & 0.46642 & 2st S-T & 0.46619 & 1st S-T & 0.46417 & 1st A-VB & 0.46155 & 2st S-T \\
\hline
\end{tabular}




\section{Effects of the stiffness of suspender}

The stiffness of the suspender depend on the cross-sectional area. The paper use relative stiffness coefficient $\eta_{2}$ to represent the change of stiffness, $\eta_{2}=\frac{E A}{E_{0} A_{0}}$, where $E_{0} A_{0}$ represents the standard stiffness, EA represents the changed stiffness. Modal analysis of the effects of the stiffness of suspender is shown in table 8 which list the fist ten mode shapes only.

Table 8 Dynamic responses of suspension bridge with different $\eta_{2}$

\begin{tabular}{|c|c|c|c|c|c|c|c|c|c|c|}
\hline \multirow{3}{*}{$\begin{array}{l}\text { Mode } \\
\text { No. }\end{array}$} & \multicolumn{10}{|c|}{$\eta_{2}$} \\
\hline & \multicolumn{2}{|c|}{0.5} & \multicolumn{2}{|r|}{0.8} & \multicolumn{2}{|r|}{1} & \multicolumn{2}{|r|}{1.5} & \multicolumn{2}{|c|}{2} \\
\hline & $\begin{array}{c}\text { Frequency } \\
(\mathrm{Hz})\end{array}$ & $\begin{array}{l}\text { Mode shape } \\
\text { description }\end{array}$ & $\begin{array}{c}\text { Frequency } \\
(\mathrm{Hz})\end{array}$ & $\begin{array}{l}\text { Mode shape } \\
\text { description }\end{array}$ & $\begin{array}{c}\text { Frequency } \\
\text { (Hz) }\end{array}$ & $\begin{array}{l}\text { Mode shape } \\
\text { description }\end{array}$ & $\begin{array}{c}\text { Frequency } \\
(\mathrm{Hz})\end{array}$ & $\begin{array}{l}\text { Mode shape } \\
\text { description }\end{array}$ & $\begin{array}{c}\text { Frequency } \\
(\mathrm{Hz})\end{array}$ & $\begin{array}{c}\text { Mode shape } \\
\text { description }\end{array}$ \\
\hline 1 & 0.069545 & 1st S-HB & 0.069555 & 1st S-HB & 0.069555 & 1st S-HB & 0.06955 & 1st S-HB & 0.070146 & 1st S-HB \\
\hline 2 & 0.15586 & 1st A-VB & 0.15604 & 1st A-VB & 0.15607 & 1st A-VB & 0.15606 & 1st A-VB & 0.15842 & 1st A-VB \\
\hline 3 & 0.17523 & 2st A-HB & 0.17521 & 2st A-HB & 0.17517 & 2st A-HB & 0.17506 & 2st A-HB & 0.1781 & 2st A-HB \\
\hline 4 & 0.18078 & 2st A-VB & 0.18093 & 2st A-VB & 0.18097 & 2st A-VB & 0.18101 & 2st A-VB & 0.18859 & 2st A-VB \\
\hline 5 & 0.26427 & 3st S-VB & 0.26541 & 3st S-VB & 0.26573 & 3st S-VB & 0.26598 & 3st S-VB & 0.29044 & 3st S-VB \\
\hline 6 & 0.28761 & 4st A-VB & 0.28847 & 4st A-VB & 0.28869 & 2st A-VB & 0.28881 & 4st A-VB & 0.31332 & 4st A-VB \\
\hline 7 & 0.31507 & 2st S-HB & 0.31499 & 2st S-HB & 0.31492 & 2st S-HB & 0.31473 & 2st S-HB & 0.33091 & 2st S-HB \\
\hline 8 & 0.38068 & 5st S-VB & 0.38248 & 5st S-VB & 0.383 & 4st S-VB & 0.38346 & 5st S-VB & 0.39937 & 5st S-VB \\
\hline 9 & 0.38875 & 1st S-T & 0.38972 & 1st S-T & 0.38997 & 1st S-T & 0.39011 & 1st S-T & 0.44026 & 1st S-T \\
\hline 10 & 0.46688 & 2st S-T & 0.46654 & 2st S-T & 0.46619 & 2st S-T & 0.46517 & 2st S-T & 0.46155 & 2st S-T \\
\hline
\end{tabular}

According to the results in table 8, the fundamental frequency of suspension bridge change little with the stiffness of the suspender change, the relative variation ratio is $0.5 \%$ only, when the relative stiffness coefficient change from 1.5 to 2 , so the stiffness of the suspender change have little effect on the dynamic responses of suspension bridge.

\section{Conclusions}

The research results show the basic frequency of vertical, lateral bending and twist of suspension bridge with CFRP cables were increased in contrast with suspension bridge with steel cables, applying CFRP cable has little effect on the mode shapes and frequencies of horizontal bending and longitudinal floating of stiffening girder. The central buckle make the entire stiffness of suspension bridge increase, it restrict the longitudinal displacement of the bridge also, so the central buckle could improve the dynamic behavior of suspension bridge, the frequency not always increase with the stiffness of main cables increase. The stiffness of suspender have relatively a small effect on the dynamic behavior of the entire suspension bridge.

\section{References}

[1] Yan Guomin. Modern suspension bridge. Beijing: china communication press, 2002:22-25.

[2] Zheng Hongyu, Mei Kuihua, Lu Zhitao. Research of advantages and feasibility of suspension bridge to be used with CFRP cable system[J]. Bridge Construction, 2006(4):7-10.

[4] Ye Huawen, UMMENHOFER T, Qiang Shizhong, Experimental study of flexural fatigue performance of steel girder reinforced by prestressed CFRP plate[J]. Journal of Highway and Transportation Research and Development, 2009,26(12):50-55.

[5] Elsevier Ltd. Building better bridges with CFRP[J]. Reinforced Plastics, 1998,42(3):44-47. 
[6] Mei Kuihua, Bi Yinbo, Zhang Hao. Study of structural measures for improving wind resistance stability of long-span suspension bridge with CFRP cables[J]. Bridge Construction, 2011(5):26-30.

[7] Xie Xu, Zhu Yuefeng. Study on behavior of long-span CFRP cable-stayed bridges[J]. Engineering mechanics, 2007,24(11):113-120.

[8] Chen Renfu.Theory of long-span suspension[M]. Chengdu: Southwest Jiaotong University Press, 1994:52-53.

[9] Liu Shuwei. Analysis of static-dynamic mechanics performance of long-span suspension bridges[M]. Changan University, 2007.

[10] Yang Wenjie. Analysis on dynamic properties of large-span cable-stayed bridge based on ANSYS[J]. Shanxi architecture,2013, 39(30):178-179. 